\title{
Characterization of Polysaccharide Accumulations in a Cell Division Defective Mutant of Escherichia coli 15T-
}

\author{
By J. M. SCHOEMAKER, ${ }^{\dagger}$ J. M. CLARK $\ddagger$ AND J. J. SAUKKONEN \\ Department of Microbiology, Thomas Jefferson University, Philadelphia, \\ Pennsylvania 19107, U.S.A.
}

(Received 1 August 1980; revised 17 October 1980)

\begin{abstract}
Escherichia coli $15 \mathrm{~T}^{-} \mathrm{R}_{1}$, a temperature-dependent cell division mutant, grows into filaments of various lengths $(200$ to $500 \mu \mathrm{m})$ at $24^{\circ} \mathrm{C}$, but divides essentially normally at $37^{\circ} \mathrm{C}$. When grown to late-exponential phase at the restrictive temperature, the elongated cells showed discrete areas of increased density at polar regions and other sites in the cytoplasm, when viewed by phase contrast microscopy. Electron microscopy of preparations specifically stained for polysaccharide revealed clusters of granules with a similar distribution pattern to that of the dense areas seen by phase contrast microscopy. The granules were susceptible to $\alpha$-amylase digestion, and chemical analysis of the extracted and purified polysaccharide showed that it consisted of polyglucose, including glycogen. At $24^{\circ} \mathrm{C}$ the $\mathrm{R}_{1}$ cells contained about twice as much polyglucose and four times as much glycogen as at $37^{\circ} \mathrm{C}$.
\end{abstract}

\section{INTRODUCTION}

Under conditions of unbalanced growth the cytoplasm of bacterial cells can contain inclusion bodies such as those consisting of polyphosphate, polysaccharide or $\beta$-hydroxybutyrate (Shively, 1974). These formations are usually visualized in light or electron microscopy by employing specific staining techniques. In certain instances inclusions can be seen in unstained cells. For example, membrane-associated protein inclusions which have been shown to accumulate in a temperature-sensitive growth mutant of Bacillus subtilis at the restrictive temperature were seen as dense areas in the region of the septum by phase contrast microscopy (Behme \& Fitz-James, 1972). Similar membrane-associated inclusions were seen in an arginine-requiring strain of Escherichia coli undergoing 'canavanine death' (Schachtele \& Rogers, 1968): the cells grown in the presence of the amino acid analogue canavanine showed distinct, round dark areas in their cytoplasm when viewed by phase contrast microscopy.

The present study was prompted by the observation of intracytoplasmic inclusions in unstained cells of certain strains of $E$. coli $15 \mathrm{~T}^{-}$when viewed by phase contrast microscopy. The formations were especially prominent in $E$. coli $15 \mathrm{~T}^{-} \mathrm{R}_{1}$, a low temperature-conditional cell division mutant, when grown to late-exponential phase at the restrictive temperature. Due to arrest of division, the cells grew to long filaments in which the accumulations appeared as dense areas at discrete locations throughout the cytoplasm. In this report we show that the accumulations consist of clusters of polyglucose (predominantly glycogen) granules.

\footnotetext{
† Present address: Department of Microbiology, The University of Chicago, Chicago, Illinois 60637, U.S.A.

$\ddagger$ Present address: Department of Biology, University of Alabama in Huntsville, Huntsville, Alabama 35807 , U.S.A.
} 


\section{METHODS}

Bacterial strains. Escherichia coli $15 \mathrm{~T}^{-}$, a quadruple auxotroph of E. coli 15 requiring thymine, arginine, methionine and tryptophan for growth, was originally obtained from Karl G. Lark, and has been maintained in this laboratory. This strain is referred to in the text as the parental strain or $S_{1}$. A low temperature-dependent cell division mutant was isolated from among rough colony variants of $S_{1}$, and designated strain $R_{1}$ (Saukkonen, 1968).

Media and growth conditions. The bacteria were grown in a modified M9 medium (Pritchard \& Lark, 1964), supplemented with the following components, per litre: $4 \mathrm{~g}$ glucose, $20 \mathrm{mg}$ thymine, $340 \mathrm{mg}$-arginine, $300 \mathrm{mg}$ L-methionine and $140 \mathrm{mg}$ L-tryptophan. For preparation of M9 agar, Difco Special Noble agar was added to a final concentration of $1.5 \%(\mathrm{w} / \mathrm{v})$. The cultures were routinely maintained on $\mathrm{M} 9$ agar at $37^{\circ} \mathrm{C}$. Growth of suspension cultures was monitored by measuring the absorbance at $540 \mathrm{~nm}$ in a Coleman Hitachi 124 spectrophotometer.

Light microscopy. To enhance the contrast of cytoplasmic structures for phase contrast microscopy, the refractive index of the M9 agar was adjusted by addition of polyvinylpyrrolidone K-90 (PVP) to a final concentration of $8 \%(\mathrm{w} / \mathrm{v})$ (Schaechter et al., 1962). Samples of suspension cultures were placed on $1 \mathrm{~mm}$ thick M9-PVP agar blocks $(10 \times 10 \mathrm{~mm})$, excess medium was drained off, a coverslip was placed over the preparation, and the cells were photographed using a Carl Zeiss microscope equipped with phase contrast optics and a Zeiss Ikon camera. Kodak Plus X Pan film was used. Cells were stained for polysaccharide with a periodic acid-Schiff technique (Norris \& Swain, 1971), for polyphosphate according to Ruthman (1970) and for lipid by the procedure described by Burdon (1946).

Electron microscopy. To orientate the filamentous cells in one plane for thin sectioning, cells were evenly spread over the surface of M9 agar and impression smears were made on to glass coverslips. Standard fixation was achieved by immersing the coverslips in $3 \%(\mathrm{v} / \mathrm{v})$ glutaraldehyde in $0.067 \mathrm{M}$-sodium cacodylate buffer, containing $1 \%(\mathrm{w} / \mathrm{v})$ sucrose, $\mathrm{pH} 7.2$ to 7.4 , for $15 \mathrm{~min}$ at $24^{\circ} \mathrm{C}$. This was followed by washing in cacodylate buffer and postfixation in $1 \%(\mathrm{v} / \mathrm{v}) \mathrm{OsO}_{4}$ in the same buffer for $15 \mathrm{~min}$ at $24{ }^{\circ} \mathrm{C}$. Samples were dehydrated through a graded series of ethanol and ethanol/Epon mixtures. The coverslips, with adherent cells facing up, were placed in a plastic Petri dish and covered with the embedding resin Epon 812. Following polymerization at $60{ }^{\circ} \mathrm{C}$ for $36 \mathrm{~h}$, liquid nitrogen was poured over the Petri dish and coverslip so that they could be removed. In the superficial layer of the block, areas containing cells were located by light microscopy and thin sections were obtained from these areas by cutting parallel to the surface of the block using a Porter Blum MT-2 ultramicrotome equipped with a diamond knife. Conventional staining consisted of treatment with uranyl acetate for $5 \mathrm{~min}$ (Glauert, 1965), followed by lead citrate for $3 \mathrm{~min}$ (Reynolds, 1963). For some studies cells were embedded in the water-soluble embedding medium glycol methacrylate according to the method of Leduc \& Bernhard (1967). To stain specifically for carbohydrate, a procedure involving treatment of the thin sections with periodic acid, thiosemicarbazide and silver proteinate (PA-TSC-SP) was used (Thiery, 1967). All preparations were examined and photographed in a Hitachi model HS-8 electron microscope. All reagents for electron microscopy were obtained from Electron Microscopy Sciences (Fort Washington, Pa, U.S.A.).

Enzyme treatment. Thin sections of cells mounted on gold grids were digested with enzymes as described by Monneron \& Bernhard (1966). Grids were floated, specimen side down, on droplets of $0.1 \%(\mathrm{w} / \mathrm{v})$ aqueous porcine pancreatic $\alpha$-amylase (EC 3.2.1.1), $0.5 \%(\mathrm{w} / \mathrm{v})$ pepsin (EC 3.4.23.1) from hog stomach mucosa in $0.1 \mathrm{M}-\mathrm{HCl}, 0.5 \%(\mathrm{w} / \mathrm{v})$ protease from Streptomyces griseus or on $0.5 \%(\mathrm{w} / \mathrm{v})$ bovine pancreatic ribonuclease (EC 3.1.27.5). Incubation with the enzyme solutions was carried out for a minimum of $3 \mathrm{~h}$ in a moist chamber at $37^{\circ} \mathrm{C}$. Control sections were incubated on water droplets under the same conditions. Some sections were pretreated with $10 \%(\mathrm{v} / \mathrm{v}) \mathrm{H}_{2} \mathrm{O}_{2}$, which is thought to facilitate the penetration of enzymes into Epon as a result of the solubilization of cell-bound osmium (Monneron \& Bernhard, 1966). Ribonuclease and $\alpha$-amylase were purchased from Worthington Biochemical Corp. and pepsin and protease from Sigma.

Extraction of polysaccharide. Polysaccharide was extracted according to a modification of the method of Sigal et al. (1964). Growth of late-exponential phase cultures was stopped by the addition of an equal volume of $95 \%$ ethanol. The cultures were harvested by centrifugation at $8000 \mathrm{~g}$ for $15 \mathrm{~min}$ in the cold, and the resulting pellets were washed twice in cold acetone and hydrolysed in $30 \%(\mathrm{w} / \mathrm{v}) \mathrm{KOH}$ in a boiling water bath for $75 \mathrm{~min}$. For precipitation of the alkali-stable polysaccharide, 1.1 vol. $95 \%$ ethanol was added to the cooled digest. After overnight incubation at $4{ }^{\circ} \mathrm{C}$ the polysaccharide was collected by centrifugation at $18000 \mathrm{~g}$ for $15 \mathrm{~min}$ in the cold. The pellet was dissolved in distilled water, centrifuged at $4000 \mathrm{~g}$ for $10 \mathrm{~min}$ to remove insoluble particulate matter, followed by precipitation of polysaccharide by addition of 1 vol. absolute ethanol to the supernatant, and collection of the white precipitate by centrifugation at $18000 \mathrm{~g}$ for $15 \mathrm{~min}$. The precipitate was washed with acetone and dried in vacuo at $37^{\circ} \mathrm{C}$ to constant weight. The total yield from $3800 \mathrm{ml}$ culture ( $5 \mathrm{~g}$ dry wt cells) was approximately $200 \mathrm{mg}$.

Characterization of purified polysaccharide. For determination of the $\beta$-D-glucose content, the method of Sigal et al. (1964) was used. Purified polysaccharide was hydrolysed in $1 \mathrm{M}-\mathrm{H}_{2} \mathrm{SO}_{4}$ for $2 \mathrm{~h}$ in a boiling water bath, cooled, neutralized with $2 \mathrm{M}-\mathrm{K}_{2} \mathrm{HPO}_{4}$, and glucose was estimated using a glucose oxidase assay (Glucostat, Worthington). 
Chromatography of hydrolysed $15 \mathrm{~T}^{-} \mathrm{R}_{1}$ polysaccharide was carried out on cellulose thin-layer plates (Bakerflex) in three different solvent systems: 1-butanol/pyridine/water $(6: 4: 3$, by vol.), 1-butanol/acetic acid/water ( $3: 1: 1$, by vol.), ethyl acetate/pyridine/water (12:5:4, by vol.), along with appropriate reference compounds. The plates were sprayed with an aniline phosphate reagent to locate sugars (Zweig \& Sherma, 1972).

The absorption spectrum of the polysaccharide-iodine complex was determined according to Archibald et al. (1961), using a solution containing $0.01 \%$ polysaccharide and $0.02 \% \mathrm{I}$ in $0.2 \% \mathrm{KI}$, in a Coleman Hitachi double-beam spectrophotometer equipped with a recorder.

For characterization of the linkages in the purified polysaccharide, the extracted material was treated with amyloglucosidase (EC 3.2.1.3; Sigma) according to Marshall \& Whelan (1970). Released glucose was assayed with the glucose oxidase reagent. For reference, rabbit liver glycogen was subjected to the same enzymic treatment.

Estimation of bacterial polysaccharide content. Total polyglucose in bacterial cultures was determined by the

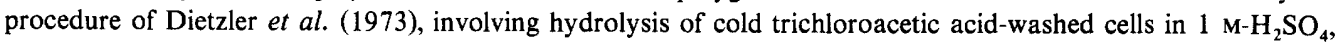
neutralization with $2 \mathrm{M}-\mathrm{K}_{2} \mathrm{HPO}_{4}$ and filtration to remove cellular debris. Glucose in the filtrate was then quantified with the glucose oxidase assay.

For determination of the glycogen content of bacterial cultures, an adaptation of the method of Steiner \& Preiss (1977) was used. Washed cells were hydrolysed in $2 \mathrm{M}-\mathrm{KOH}$, cooled and the pH was adjusted with $1.75 \mathrm{M}$-acetic acid to 5.2 . Glycogen was converted to glucose by digestion with amyloglucosidase, and assayed using the glucose oxidase procedure. When known amounts of rabbit liver glycogen were subjected to this procedure, $100 \pm 2 \%$ of the material could be accounted for, indicating that the enzyme treatment hydrolysed all 1,4- $\alpha$ - and 1,6- $\alpha$-glycosidic linkages.

\section{RESULTS AND DISCUSSION}

\section{Observations of cells by phase contrast microscopy}

In a culture of $R_{1}$ cells grown at the restrictive temperature of $24^{\circ} \mathrm{C}$, the average cell length increased with time as a result of the cell division defect. By the late-exponential phase the culture consisted of a population of cells of various sizes (Fig. 1a) ranging from
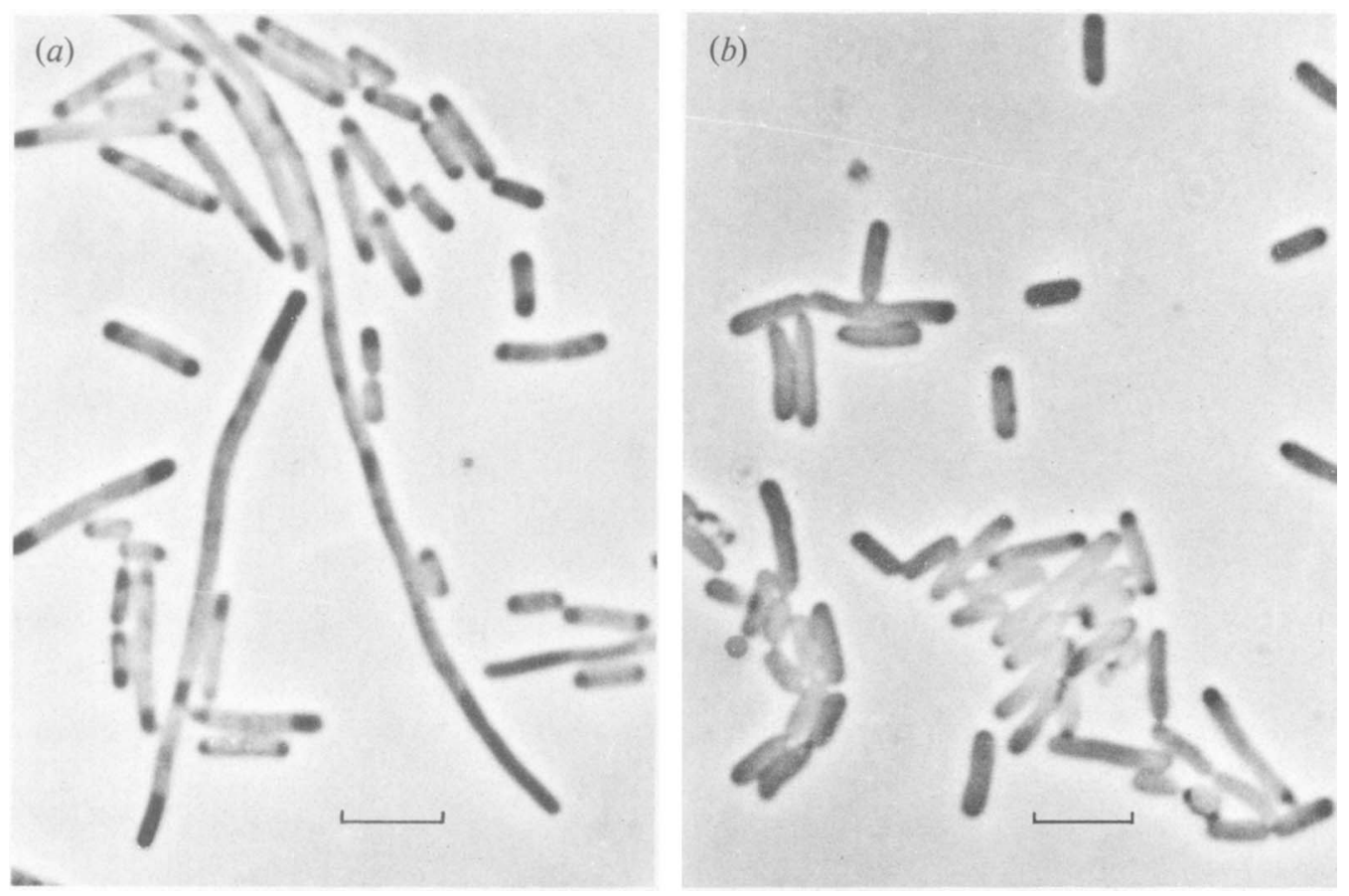

Fig. 1. Phase contrast micrographs of late-exponential phase $15 \mathrm{~T}^{-} \mathbf{R}_{1}$ cells on PVP agar. (a) Cells grown at $24^{\circ} \mathrm{C}$ showing large dense (dark) areas at the poles and at discrete sites throughout the cytoplasm of filamentous cells. (b) Cells grown at $37^{\circ} \mathrm{C}$ showing cytoplasm of homogeneous appearance except for dark polar 'caps' in some cells. The bar markers represent $2 \mu \mathrm{m}$. 
$2 \mu \mathrm{m}$ up to $500 \mu \mathrm{m}$ in length. When cells from a culture growing at $24^{\circ} \mathrm{C}$ were placed on PVP agar and viewed at intervals by phase contrast microscopy, areas of increased density gradually appeared at the poles and at discrete sites throughout the cytoplasm of
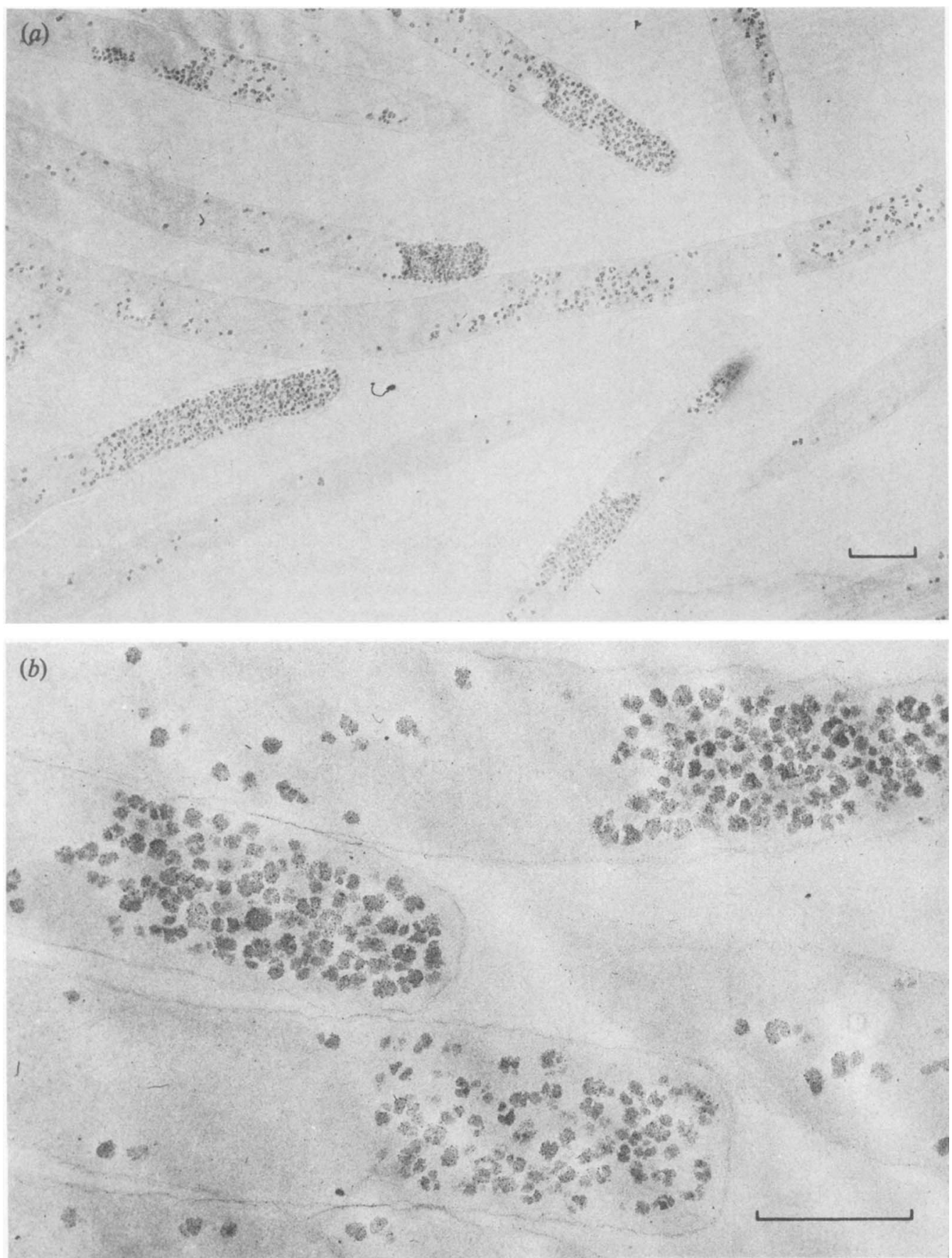

Fig. 2. Electron micrographs of late-exponential phase $15 \mathrm{~T}^{-} \mathrm{R}_{1}$ cells grown at $24^{\circ} \mathrm{C}$ and stained with PA-TSC-SP. Cells show clusters of silver-stained granules at poles and at discrete sites throughout the cytoplasm, and individual granules near the cytoplasmic membrane. Note the rosette-like appearance of granules at high magnification. The bar markers represent $1 \mu \mathrm{m}$ in $(a)$ and $0.5 \mu \mathrm{m}$ in $(b)$. 
the elongated bacteria. The dense areas were most prominent in the late-exponential phase (Fig. 1 $a$ ), and cultures of this age were used for subsequent ultrastructural and biochemical studies.

In contrast, the cytoplasm of late-exponential phase $R_{1}$ cells grown at $37^{\circ} \mathrm{C}$ (cells of 2 to $10 \mu \mathrm{m}$ in length) or of the parental $\mathrm{S}_{1}$ cells $(2$ to $4 \mu \mathrm{m}$ ) appeared relatively homogeneous. Occasionally, dark polar 'crescents' or 'caps' could be seen in some cells; however, it was difficult to discern whether or not these were optical artifacts, or similar in nature to the formations seen in the filamentous cells (Fig. $1 b$ ).

\section{Examination using specific stains}

As phase contrast microscopy gives no information about the chemical nature of the material under observation, more specific staining techniques were tried. The clusters in $R_{1}$ cells did not show any affinity for stains specific for polyphosphate or lipid, but they were stained by the periodic acid-Schiff procedure for visualization of polysaccharides under light microscopy, and by its counterpart for electron microscopy, the PA-TSC-SP stain. The PA-TSC-SP technique will give positive results with any substance that has the 1,2-glycol grouping in unsubstituted form (Pearse, 1961). Thus, ribo- and deoxyribonucleic acids will not react, but many types of carbohydrates will give a positive reaction.

When this technique was employed, intensely stained granules were observed in the cells, predominantly at the poles, at discrete areas elsewhere in the cytoplasm and, in some instances, lining the periphery of the cell (Fig. 2). The granules, which ranged in diameter from 40 to $80 \mathrm{~nm}$, often appeared to be composed of two or three subunits (Fig. $2 \mathrm{~b}$ ) and resembled the rosette-like glycogen particles first described in metazoan cells by Drochmans (1962). The following experiments were conducted to determine the specificity of the PA-TSC-SP technique in our hands. (1) To examine whether the staining was due to the presence of aldehyde groups in the embedded cells prior to PA oxidation, thin sections were treated with TSC-SP: no silver staining was visible indicating that aldehyde groups did not persist in the cells, e.g. as a result of fixation in glutaraldehyde. (2) To examine for the presence of groups that could reduce silver proteinate to metallic silver following PA oxidation, thin sections were treated with PA-SP: no silver staining of cells resulted. (3) Treatment of cells with PA followed by the aldehyde-blocking agent sodium borohydride, and then by TSC-SP did not stain the granules, indicating that the PA treatment did not create, in addition to aldehydes, other groups capable of reducing silver following TSC treatment.

\section{Enzyme treatment of thin sections}

For further characterization of the nature of the granular material, thin sections were subjected to treatment with various enzymes. Incubation with $0.1 \%$ aqueous $\alpha$-amylase followed by PA-TSC-SP resulted in cells containing distinct, small translucent areas of the size of the granules. These rapidly became fully transparent 'holes' in the plastic after prolonged exposure to the electron beam (Fig. $3 a$ ). The hole formation was not observed in control sections treated with water-TSC-SP, although these cells had similar translucent areas. Therefore, the tendency for hole formation in the enzymically treated sections probably resulted from the actual loss of material at the sites of the granules, making these loci thinner and more susceptible to beam damage.

The dissolution of the granules was gradual, requiring an extended period of enzyme treatment for completion. After a $3 \mathrm{~h}$ incubation with $\alpha$-amylase followed by PA-TSC-SP, 'translucent granules' (areas of low' contrast), partially stained granules, and intensely stained granules were all visible in the cells (Fig. $3 b$ ). However, after $5 \mathrm{~h}$ incubation, only translucent granules were seen. To verify that this loss of granular material was actually due to enzymic digestion, rather than to a non-specific extraction caused by incubation of the sections in aqueous solutions, control sections were floated on water for 3 to $5 \mathrm{~h}$ in the 

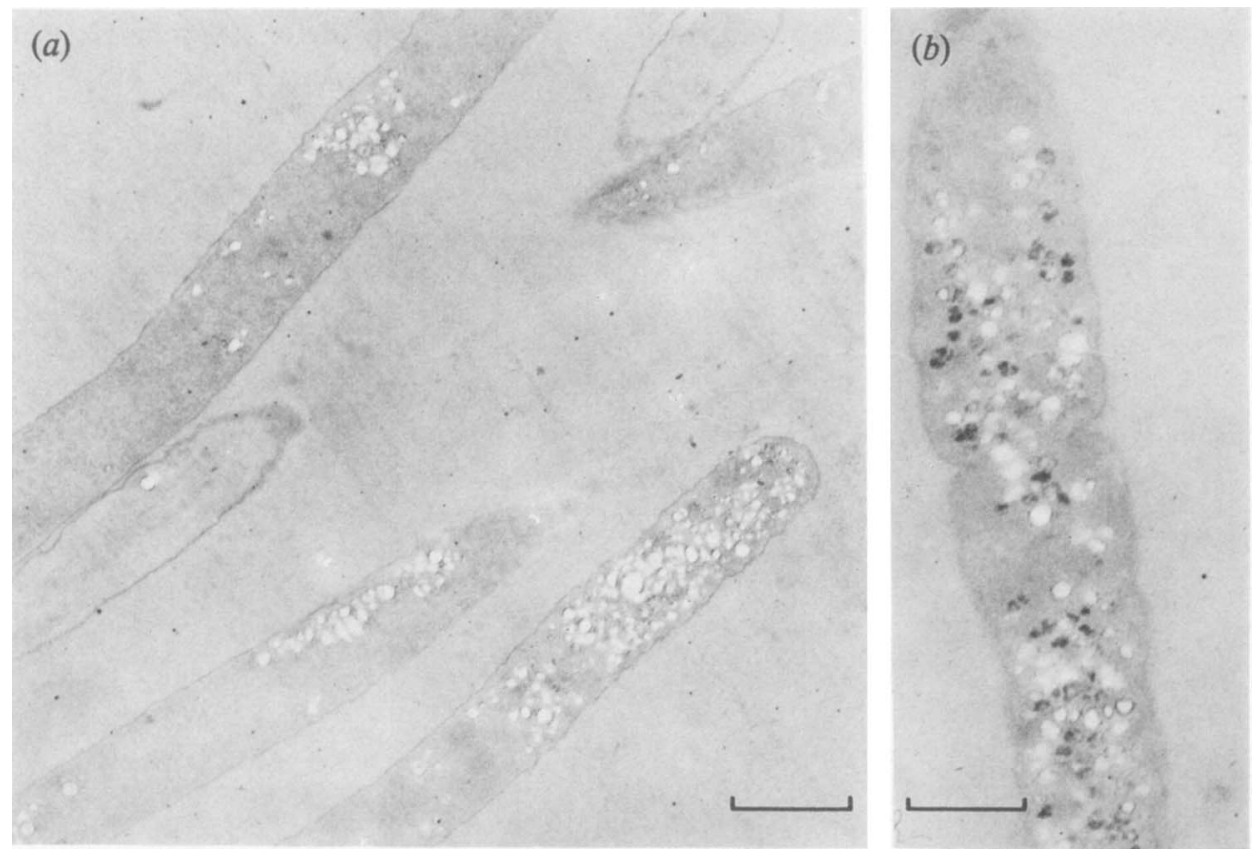

Fig. 3. Electron micrographs of late-exponential phase $15 \mathrm{~T}^{-} \mathrm{R}_{1}$ cells grown at $24^{\circ} \mathrm{C}$. (a) Cells showing enlarged 'holes' at the sites of former granules after treatment of thin sections with $0.1 \% \alpha$-amylase for $5 \mathrm{~h}$ followed by staining with PA-TSC-SP. The bar marker represents $1 \mu \mathrm{m}$. (b) Mixture of silver-stained granules and holes present after $3 \mathrm{~h}$ treatment with enzyme before staining. The bar marker represents $0.5 \mu \mathrm{m}$.

absence of the enzyme, and then treated with PA-TSC-SP. No translucent areas were seen, i.e. only intensely stained granules were visible in these cells. When sections were incubated on a solution of $0.1 \% \alpha$-amylase inactivated in $8 \mathrm{M}$-urea (Toralballa \& Eitingon, 1967), only intensely stained granules were seen following treatment with PA-TSC-SP.

There have been several reports that polysaccharide granules in other types of cells may be bound to proteins (Reissig \& Orrell, 1970; Rosati, 1967; Vye \& Fischman, 1971). The possibility that other substances might also be associated with the granules in $\mathbf{R}_{1}$ was explored. Thin sections fixed by the standard procedure were embedded in either Epon or glycol methacrylate (GMA). The use of an embedding plastic like GMA is thought to facilitate the rapid penetration of aqueous enzyme solutions and the subsequent removal of cellular components. Unlike the epoxy resins, GMA is water-soluble, is not cross-linked and has a relatively low viscosity (Leduc et al., 1963; Leduc \& Bernhard, 1967; Vasquez-Nin $\&$ Bernhard, 1971). Thin sections were incubated on solutions of pepsin, protease and ribonuclease. After as long as $10 \mathrm{~h}$ exposure to these enzymes [with or without preoxidation with $10 \%(\mathrm{v} / \mathrm{v}) \mathrm{H}_{2} \mathrm{O}_{2}$ ], followed by treatment with PA-TSC-SP, there was no indication that specific extraction or modification of the granular material had occurred.

Electron micrographs of PA-TSC-SP-stained, late-exponential phase $\mathrm{R}_{1}$ cells grown at the non-restrictive temperature of $37^{\circ} \mathrm{C}$, as well as of the parental $\mathrm{S}_{1}$ cells grown at either 24 or $37^{\circ} \mathrm{C}$, demonstrated the presence of a small number of dense granules at the poles and occasionally lining the periphery of the cell (Fig. 4). These granules were susceptible to $\alpha$-amylase digestion, but not to treatment with other enzymes.

\section{Electron microscopy of conventionally stained preparations}

In bacterial cells, including $E$. coli, polysaccharide (glycogen) has been often identified as electron-translucent granules of approximately 60 to $100 \mathrm{~nm}$ in diameter following fixation 


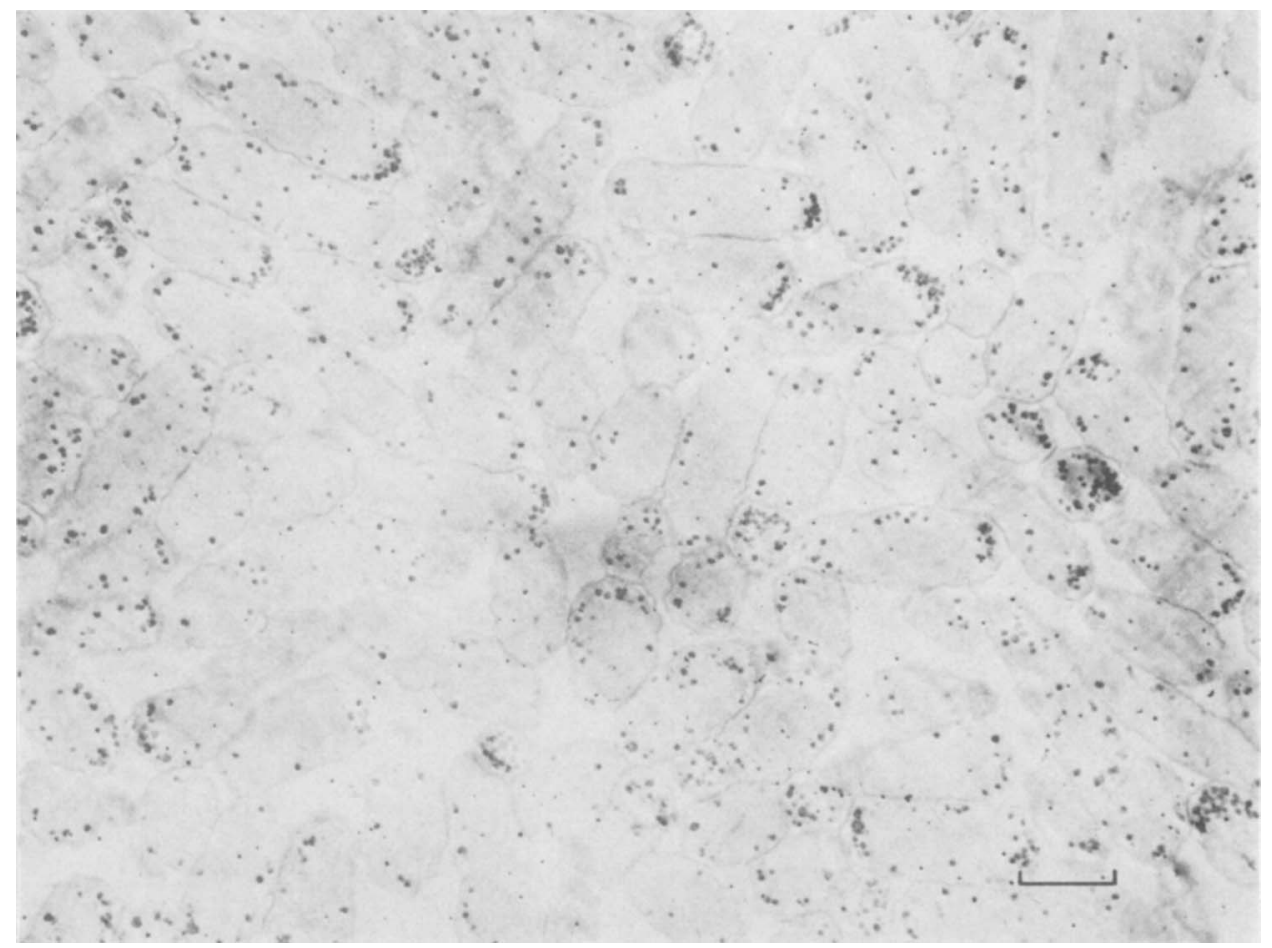

Fig. 4. Electron micrograph of late-exponential phase $15 \mathrm{~T}^{-} \mathrm{R}_{1}$ cells grown at $37^{\circ} \mathrm{C}$ and stained with PA-TSC-SP. Small clusters of silver-stained granules can be seen at the peripheral areas of cells, particularly at the poles. The bar marker represents $1 \mu \mathrm{m}$.

in osmium tetroxide (Cedergren \& Holme, 1959; Holme \& Cedergren, 1961), or following conventional fixation and staining (Boylen \& Pate, 1973; Cheng et al., 1973; Dipersio et al., 1974). In other studies, however, polysaccharide accumulations have been seen as electrondense granules (Craig \& Williamson, 1972; Robertson et al., 1975).

To examine the appearance of polysaccharide in conventionally stained $R_{1}$, thin sections of late-exponential phase cells grown at $24^{\circ} \mathrm{C}$ were stained with uranyl acetate and lead citrate and examined by electron microscopy. Clusters of granular material were seen in the cytoplasm. However, the appearance of the granules varied considerably. Groups of either electron-dense granules, translucent granules or a combination of both could be seen in the cells (Fig. 5). Variable staining of polysaccharide, similar to that seen in $\mathrm{R}_{1}$, has been reported in a study of nerve cells of frog muscle in which glycogen granules appeared either as dense particles or ring-like structures with translucent centres (Thornell et al., 1977). The appearance of polysaccharide granules can thus vary from one organism to another, as well as within the same cell. This variability of staining may be due to structural differences between granules leading to different affinities to conventional stains, or to differences in the size of granules resulting in a difference in the degree of uptake of stain.

\section{Properties of the purified polysaccharide}

The material extracted and purified from late-exponential phase $\mathrm{R}_{1}$ cells grown at $24{ }^{\circ} \mathrm{C}$ was a white powder. $\beta$-D-Glucose accounted for essentially all of the mass of the purified material $(99.8 \%)$ as determined by liberation of glucose by acid hydrolysis. In addition, thin-layer chromatography of hydrolysates of the purified material in three different solvent systems revealed only one hydrolysis product having an $R_{F}$ value identical to that of glucose. In order to characterize the linkages in the purified polysaccharide, the material was 

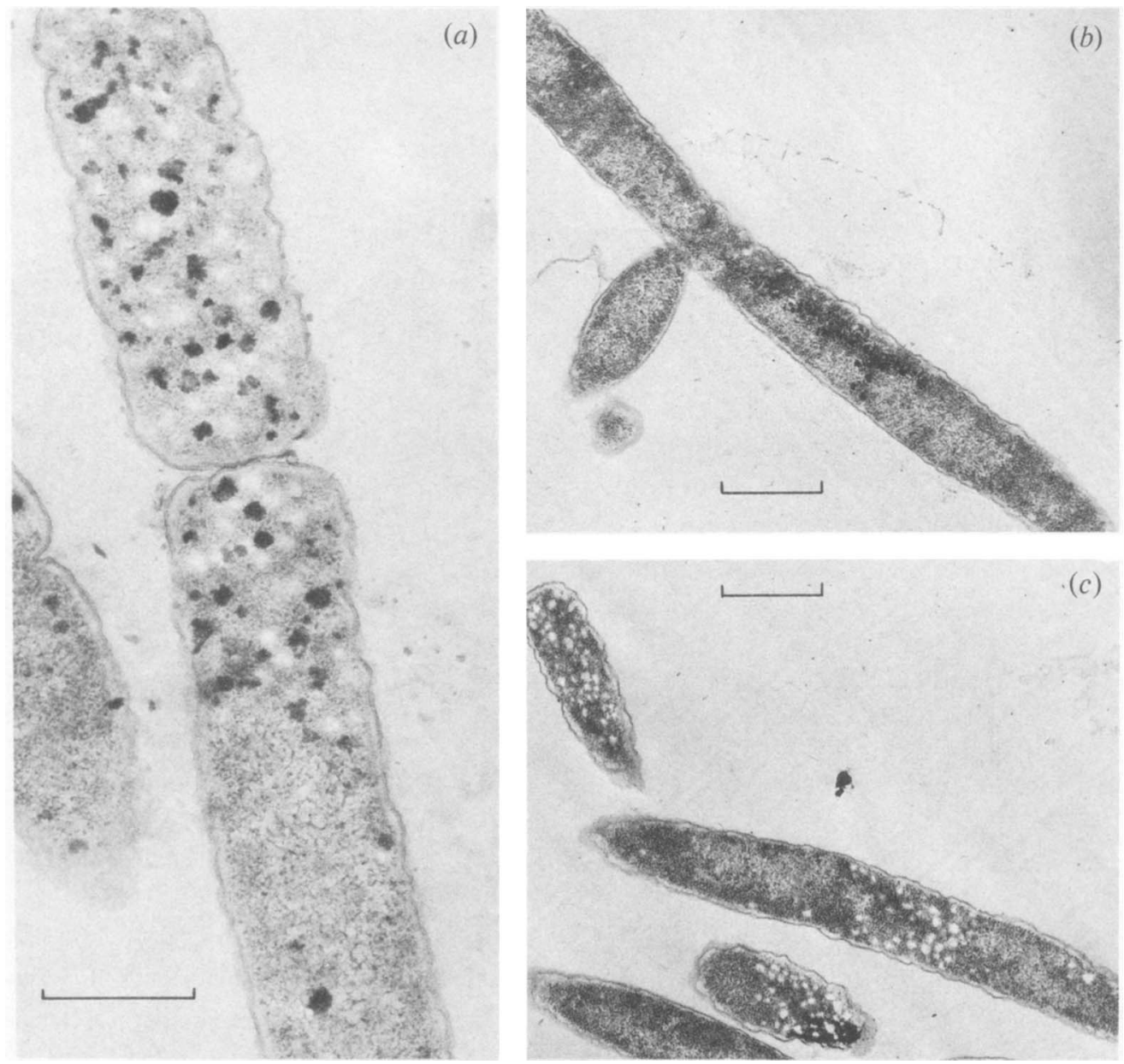

Fig. 5. Electron micrographs of late-exponential phase $15 \mathrm{~T}^{-} \mathrm{R}_{1}$ cells grown at $24^{\circ} \mathrm{C}$ showing the variable appearance of granules when stained with uranyl acetate and lead citrate. (a) Combination of intensely stained granules and translucent granules (areas of low contrast) in the same cell. The bar marker represents $0.5 \mu \mathrm{m}$. $(b, c)$ Cells, in the same thin section, exhibiting either only densely stained granules or only translucent granules, respectively. The bar markers represent $1 \mu \mathrm{m}$.

incubated with amyloglucosidase. This enzyme hydrolyses both the 1,4- $\alpha$-and 1,6- $\alpha$-glucosidic linkages of starch and glycogen resulting in the successive removal of glucose units from the non-reducing ends of the molecule, bringing about a quantitative conversion of polysaccharide to glucose (Marshall \& Whelan, 1970). Enzymic digestion for $3 \mathrm{~h}$ liberated the maximum amount of glucose, equal to approximately $87 \%$ of the amount liberated by acid hydrolysis.

The absorption spectrum of the iodine-polysaccharide complex indicated that the $\lambda_{\max }$ (425 nm) and $A_{\max }(0.2)$ of the $\mathrm{R}_{1}$ polysaccharide were more characteristic of glycogen ( $\lambda_{\max } 420$ to $490 \mathrm{~nm}, A_{\max } 0 \cdot 1$ to 0.4 ) than of amylopectin-type polysaccharide $\left(\lambda_{\max } 530\right.$ to $550 \mathrm{~nm}, A_{\max } 0.8$ to 1.2) (Archibald et al., 1961; Khandelwal et al., 1972).

\section{Quantification of the polysaccharide in $R_{1}$ and $S_{1}$}

Quantification of the polysaccharide in $\mathrm{R}_{1}$ and the parent strain $\mathrm{S}_{1}$ involved acid hydrolysis of whole cells followed by determination of $\beta$-D-glucose in the hydrolysates with glucose 
Table 1. Polyglucose and glycogen content of $15 T^{-} R_{1}$ and $S_{1}$ cells grown under different conditions

Total polyglucose was determined as glucose liberated by acid hydrolysis. Glycogen was determined as glucose liberated by amyloglucosidase digestion of alkaline extracts.

\begin{tabular}{lccc} 
Total polyglucose & \multicolumn{2}{c}{ Glycogen } \\
\cline { 2 - 4 } Sample & $\overbrace{\text { (\% of dry wt of cells) }}$ & $11-13$ & $78-79$ \\
stationary, $24^{\circ} \mathrm{C}$ & $14-16$ & $0.5-0.7$ & $24-28$ \\
exponential, $24^{\circ} \mathrm{C}$ & $2-3$ & $3 \cdot 0$ & 48 \\
-stationary, $37^{\circ} \mathrm{C}$ & $6-7$ & $4 \cdot 0$ & 55 \\
-stationary, $24^{\circ} \mathrm{C}$ & $7-8$ & 0.4 & 24
\end{tabular}

oxidase. The polyglucose content was expressed as a percentage of the dry weight of the cells (Table 1). In all cell populations, there was an increase in total polyglucose, i.e. both glycogen and non-glycogen polymers, from mid-exponential to stationary phase. However, the elongated early-stationary phase $R_{1}$ population grown at $24{ }^{\circ} \mathrm{C}$ had approximately twice the concentration of polyglucose of the early-stationary phase $R_{1}$ culture grown at $37^{\circ} \mathrm{C}$, or of the parental $\mathrm{S}_{1}$ culture.

Inspection of the electron micrographs of PA-TSC-SP-stained cells might suggest an even greater difference in polysaccharide concentrations between $R_{1}$ cultures grown at 37 and $24^{\circ} \mathrm{C}$ than that actually found by the chemical analyses (Figs 2 and 4). This apparent discrepancy can, however, be accounted for by the presence of the large cytoplasmic volume in the filamentous cells. If the concentration of polyglucose granules is expressed as the number of granules per unit area of cytoplasm, as done in a study of polysaccharide accumulation in strains of Streptococcus mutans (Dipersio et al., 1974), a closer agreement between the cytochemical and biochemical results is obtained (Schoemaker et al., 1981).

Specific quantification of polyglucose containing $1,4-\alpha$ - and/or 1,6- $\alpha$-glucosidic linkages involved amyloglucosidase digestion of the polysaccharide extracted from cells with $2 \mathrm{M}$ $\mathrm{KOH}$. As can be seen from Table 1, the amyloglucosidase-digestible fraction (glycogen) forms a significant but variable proportion of the total polyglucose under different growth conditions. Approximately $80 \%$ of the polyglucose in the filamentous $\mathrm{R}_{1}$ population (grown at $24{ }^{\circ} \mathrm{C}$ ) was glycogen, as compared to 48 to $55 \%$ of the polyglucose in the normally dividing $\mathrm{R}_{1}$ (grown at $37^{\circ} \mathrm{C}$ ) and $\mathrm{S}_{1}$ populations. It has been reported for other strains of $E$. coli that non-glycogen glucose may account for 44 to $65 \%$ of the total polyglucose content (Ward \& Glaser, 1969; Preiss et al., 1975). The nature of the non-glycogen polyglucose and the relative proportion of it versus glycogen which is involved in the formation of the granules has not been determined.

In normally dividing bacteria, glycogen generally accumulates maximally in the stationary phase when growth is limited as a result of depletion of an essential nutrient, such as nitrogen, sulphur or phosphate, or because of low pH (Krebs \& Preiss, 1975). In the mutant $R_{1}$, the increased polyglucose storage seen in cells grown at $24^{\circ} \mathrm{C}$, as compared to cells grown at $37^{\circ} \mathrm{C}$, is linked temporally with the inhibition of cell division at the restrictive temperature. This may indicate an underlying association between cell division and regulation of polysaccharide metabolism in $E$. coli.

\section{Distribution of polysaccharide in $R_{1}$}

Examination of the distribution pattern of polysaccharide accumulations in $R_{1}$ indicated that the granules tend to cluster in discrete regions of the cytoplasm rather than being diffusely scattered throughout (Fig. 2). This suggests a possible secondary level of organization within a cell, in addition to the primary organization (rosettes) seen in an individual granule. In several strains of $E$. coli as well as in other bacteria, polysaccharide granules have 
been reported to appear in clusters in the peripheral areas of the cell suggesting localized synthesis (Holme \& Cedergren, 1961; Craig \& Williamson, 1972; Petitprez \& Derieux, 1970; Thomas \& Cattaneo, 1971; Tsien \& Schmidt, 1977). In other instances glycogen granules have been seen distributed throughout the cytoplasm (Dipersio \& Deal, 1974; Dipersio et al., 1974; Lindner et al., 1979). Whether in the latter cases the granules are initially synthesized in certain discrete locations or whether their synthesis occurs diffusely throughout the cytoplasm is not known. The localization of glycogen storage to certain discrete areas in $R_{1}$ and other organisms suggests a functional compartmentation of the cytoplasm, the utility of which has been advanced with regard to certain metabolic pathways such as glycolysis (Moses, 1978).

Another interpretation of the clustering phenomenon, which does not necessarily negate the first, is that the granules are merely displaced to whatever sites are not occupied by other structural entities, mainly the nucleoids. It is worth noting, however, that the formation of other cytoplasmic inclusions does not necessarily follow the rule of 'available space'. For example, polyphosphate granules have been reported to be usually located in the central area of the cell, in the vicinity of the nucleoid (Jensen, 1968; Craig \& Williamson, 1972; Shively, 1974). The possibility that glycogen synthesis occurs at specific sites in a bacterial cell may warrant further study.

The authors wish to thank Ms Katherine Zachariasewycz for her assistance in electron microscopy and photography.

\section{REFERENCES}

Archibald, A. R., Fleming, I. D., Liddle, A. M., Manners, D. J., Mercer, G. A. \& Wright, A. (1961). a1,4-glucosans. Part XI. The absorption spectra of glycogen- and amylopectin-iodine complexes. Journal of the Chemical Society I, 1183-1190.

Behme, R. J. \& Fitz-James, P. C. (1972). Temperature-sensitive mutant of Bacillus subtilis that accumulates membrane-associated protein inclusions. Journal of Bacteriology 109, 906-915.

Boylen, C. W. \& PATE, J. L. (1973). Fine structure of Arthrobacter crystallopoietes during long-term starvation of rod and spherical stage cells. Canadian Journal of Microbiology 19, 1-5.

Burdon, K. L. (1946). Fatty material in bacteria and fungi revealed by staining dried, fixed slide preparations. Journal of Bacteriology 52, 665-680.

Cedergren, B. \& Holme, T. (1959). On the glycogen in Escherichia coli B; electron microscopy of ultra thin sections of cells. Journal of Ultrastructure Research 3, 70-73.

Cheng, K. J., Hironaka, R., Roberts, D. W. A. \& Costerton, J. W. (1973). Cytoplasmic glycogen inclusions in cells of anaerobic gram-negative rumen bacteria. Canadian Journal of Microbiology 19, 1501-1506.

Craig, A. S. \& Williamson, K. I. (1972). Three inclusions of rhizobial bacteroids and their cytochemical character. Archiv für Mikrobiologie 87, 165-171.

Dietzler, D. N., Leckie, M. P. \& Lais, C. J. (1973). Rates of glycogen synthesis and the cellular levels of ATP and FDP during exponential growth and the nitrogen limited stationary phase of Escherichia coli WA4597 (K). Archives of Biochemistry and Biophysics 156, 684-693.
DiPERSIO, J. R. \& DEAL, S. J. (1974). Identification of intracellular polysaccharide granules in thin sections of Nocardia asteroides. Journal of General Microbiology 83, 349-358.

Dipersio, J. R., Mattingly, S. T., Higgins, M. L. \& Shockman, G. D. (1974). Measurement of intracellular iodophilic polysaccharide in two cariogenic strains of Streptococcus mutans by cytochemical and chemical methods. Infection and Immunity 10, 597-604.

Drochmans, P. (1962). Morphologie du glycogène: étude au microscope électronique de colorations negatives du glycogène particulaire. Journal of Ultrastructure Research 6, 141-163.

Glauert, A. M. (1965). Section staining, cytology, autoradiography and immunochemistry. In Techniques for Electron Microscopy, p. 259. Edited by D. H. Kay. Philadelphia: F. A. Davis Co.

Holme, T. \& Cedergren, B. (1961). Demonstration of intracellular polysaccharide in Escherichia coli by electron microscopy and by cytochemical methods. Acta pathologica et microbiologica scandinavica 51, 170-186.

JENSEN, T. E. (1968). Electron microscopy of polyphosphate bodies in a blue-green alga, Nostoc pruniforme. Archiv für Mikrobiologie 62, 144152.

Khandelwal, R. L., Spearman, T. N. \& Hamilton, I. R. (1972). Isolation and characterization of glycogen from Streptococcus salivarius. Canadian Journal of Biochemistry 50. 441-442.

Krebs, E. G. \& Preiss, J. (1975). Regulatory mechanisms in glycogen metabolism. In Biochemistry of Carbohydrates, MTP International Review of Science, vol. 5, pp. 337-390. Edited by W. J. Whelan. London: Butterworths. 
Leduc, E. H. \& BernhaRd, W. (1967). Recent modifications of the glycol methacrylate embedding procedure. Journal of Ultrastructure Research 19, 196-199.

Leduc, E. H., Marinozzi, V. \& Bernhard, W. (1963). The use of water-soluble glycol methacrylate in ultrastructural cytochemistry. Journal of the Royal Microscopical Society 81, 119-130.

Lindner, J. G. E. M., Marcelis, J. H., De Vos, N. M. \& Hoogkamp-Korstanje, J. A. A. (1979). Intracellular polysaccharide of Bacteroides fragilis. Journal of General Microbiology 111, 93-99.

MARShall, J. J. \& Whelan, W. J. (1970). Incomplete conversion of glycogen and starch by crystalline amyloglucosidase and its importance in the determination of amyloceous polymers. FEBS Letters 9 , 85-88.

Monneron, A. \& Bernhard, W. (1966). Action de certaines enzymes sur des tissus inclus en epon. Journal de microscopie 5, 697-714.

Moses, V. (1978). Compartmentation of glycolysis in Escherichia coli. In Microenvironments and Metabolic Compartmentation, pp. 169-186. Edited by P. A. Srere \& R. W. Estabrook. New York: Academic Press.

NorRIS, J. R. \& SwaIN, H. (1971). Staining bacteria. Methods in Microbiology 5A, 125.

Pearse, A. G. E. (1961). Histochemistry, Theoretical and Applied, 2nd edn, p. 233. Boston: Litle Brown and Co.

Petitprez, A. \& Derieux, J. C. (1970). Mise en évidence de polysaccharides sur quelques types de bactéries. Journal de microscopie 9, 263-272.

Preiss, J., Greenberg, J. E. \& Sabraw, A. (1975). Biosynthesis of bacterial glycogen: genetic studies of a glucose $/ \mathrm{PO}_{4}$ adenyltransferase from a glycogen deficient mutant of Escherichia coli B. Journal of Biological Chemistry 250, 7631-7638.

Pritchard, R. H. \& LARK, K. G. (1964). Induction of replication by thymine starvation at the chromosome origin in Escherichia coli. Journal of Molecular Biology 9, 289.

REISSIG, M. \& ORRELL, S. (1970). A technique for electron microscopy of protein-free particle suspensions by the negative staining method. Journal of Ultrastructure Research 32, 107-117.

REYNoLDS, E. S. (1963). The use of lead citrate at high $\mathrm{pH}$ as an electron-opaque stain in electron microscopy. Journal of Cell Biology 17, 208-212.

Robertson, J. G., Lyttleton, P., Williamson, K. I. \& BATT, R. D. (1975). The effect of fixation procedures on the electron density of polysaccharide granules in Nocardia corallina. Journal of Ultrastructure Research 50, 321-332.

Rosati, G. (1967). Enzyme treatment of glycogen particles in rat liver and muscle. Journal of Ultrastructure Research 18, 444-455.

Ruthman, A. (1970). In Methods in Cell Research, p. 148. Ithaca, New York: Cornell University Press.

SaUkKonen, J. J. (1968). Biosynthesis of macro- molecular components in a temperature-dependent cell-division defective mutant of $E$. coli $15 \mathrm{~T}^{-}$. Scandinavian Journal of Clinical and Laboratory Investigation 21, Suppl. 101, 11.

Schachtele, C. F. \& Rogers, P. (1968). Mechanism of canavanine death in Escherichia coli. I. Effect of canavanine on macromolecular synthesis. Journal of Molecular Biology 34, 843-860.

Schaechter, M., Williamson, T. P., Hood, T. \& KосH, A. L. (1962). Growth, cell and nuclear division in some bacteria. Journal of General Microbiology 29, 421-434.

Schoemaker, J. M., Schoemaker, P. J. H. \& SAukKonen, J. J. (1981). Polysaccharide accumulation in the cell division defective mutant, Escherichia coli $15 \mathrm{~T}^{-}$. Microbios (in the Press).

Shively, J. M. (1974). Inclusion bodies of procaryotes. Annual Review of Microbiology 28, 167-187.

Sigal, N., Cattaneo, J. \& Segel, I. H. (1964). Glycogen accumulation by wild type and uridine diphosphate glucose pyrophosphorylase-negative strains of Escherichia coli. Archives of Biochemistry and Biophysics 108, 440-451.

Steiner, K. E. \& Preiss, J. (1977). Biosynthesis of bacterial glycogen: genetic and allosteric regulation of glycogen biosynthesis in Salmonella. Journal of Bacteriology 129, 246-253.

Thiery, J. P. (1967). Mise en évidence des polysaccharides sur coupes fines en microscopie électronique. Journal de microscopie 6, 987-1017.

Thomas, P. \& Cattaneo, J. (1971). Etude ultrastructurale et chimique des polyglucosides cytoplasmiques synthétisés par des mutants d'Escherichia coli K12. Journal de microscopie 12, 349-362.

Thornell, L. E., SJostrom, M., Karlsson, U. \& Cedergren, E. (1977). Variable opacity of glycogen in routine electron micrographs. Journal of Histochemistry and Cytochemistry 25, 1069-1073.

Toralballa, G. C. \& Eitingon, M. (1967). Action of urea and certain amide reagents on crystalline porcine pancreatic amylase. Archives of Biochemistry and Biophysics 119, 519-525.

Tsien, H. C. \& SCHMIDT, E. L. (1977). Polarity in the exponential-phase Rhizobium japonicum cell. Canadian Journal of Microbiology 23, 1274-1284.

VASQUEZ-NIN, G. \& BERNHARD, W. (1971). Comparative ultrastructural study of perichromatin and Balbiani ring granules. Journal of Ultrastructure Research 36, 842-860.

Vye, M. V. \& Fischman, D. A. (1971). A comparative study of three methods for the ultrastructural demonstration of glycogen in thin sections. Journal of Cell Science 9, 727-749.

WARD, J. B. \& Glaser, L. (1969). Turnover of UDPsugars in $E$. coli mutants with altered UDP-sugar hydrolase. Archives of Biochemistry and Biophysics 134, 612-622.

ZweIG, G. \& SHERMA, J. (1972). In CRC Handbook of Chromatography, vol. II, p. 125. Edited by G. Zweig \& J. Sherma. Cleveland: CRC Press. 